\title{
FUZZY LOGIC CONTROL APPLIED TO A PHOTOVOLTAIC SYSTEM CONNECTED TO CITY NETWORK FOR RESIDENTIAL USE
}

\begin{abstract}
W. Q. Lamas,
H. M. Tani,

L. O. M. Reis,

and A. C. Ribeiro

${ }^{\text {a }}$ Universidade de Taubaté Departamento de Engenharia Mecânica Programa de Mestrado em Eng. Mecânica Rua Daniel Danelli, s/n - Jd. Morumb CEP. 12060-440, Taubaté, São Paulo, Brasil lamaswq@gmail.com
\end{abstract}

\section{NOMENCLATURE}

A ideality factor, without unit, 1.92

B ideality factor, without unit, 1.92

$\mathrm{E}_{\mathrm{GO}}$ band of energy for the Silicon, $1.11 \mathrm{eV}$

I current in the photovoltaic cell output, A

$\mathrm{I}_{\mathrm{LG}}$ current generated in the junction by the effect of the light, A

$\mathrm{I}_{0} \quad$ saturation current, $\mathrm{A}$

$\mathrm{I}_{\text {or }}$ saturation current and the reference temperature $\left(\operatorname{Tr}=19.9693 \times 10^{-6} \mathrm{~K}\right), \mathrm{A}$

$\mathrm{I}_{\mathrm{SCR}}$ short circuit current of the cell to $28{ }^{\circ} \mathrm{C}$ and to $100 \mathrm{~mW} / \mathrm{cm}^{2}, 3.10 \mathrm{~A}$

$\mathrm{K}_{\mathrm{t}}$ temperature coefficient for current of short circuit ( $\left.\mathrm{I}_{\mathrm{SCR}}\right), 0.0017 \mathrm{~A} /{ }^{\circ} \mathrm{C}$

$\mathrm{R}_{\mathrm{S}} \quad$ electric resistance of the photovoltaic cell, $\Omega$

$\mathrm{T}$ temperature of the photovoltaic unit measured,

$\mathrm{K}$

$\mathrm{T}_{\mathrm{c}}$ temperature of the photovoltaic unit measured,

${ }^{\circ} \mathrm{C}$

$\mathrm{T}_{\mathrm{r}} \quad$ reference temperature, $301.18 \mathrm{~K}$

$\mathrm{V}$ available voltage in the photovoltaic cell output,

\section{Greek symbols}

$\lambda_{S}$ - solar radiation incident, $\mathrm{mW} / \mathrm{cm}^{2}$

\section{INTRODUCTION}

The electric power assumed a fundamental importance in the current world; the human survival would be very difficult without it. However, the growth of the world population associated to the drastic decrease of the natural energy resources is committing the conversion and the generation of energy. So for their benefits continue taking advantage by the world population, it is necessary to learn how to use it in the right measure.

Daily, in countless residences, there are wastes that happen and that indeed could be avoided, according to publications of ANEEL (2005). However, those wastes are accumulated for the register of the concessionary company of electric power and made money monthly.

This work proposes an alternative for the use of a generation system of photovoltaic energy to be used in residences, connected to the electric distribution grid of the Concessionary Companies of Electric power. This alternative has already been used in several countries. The topology proposes in that the local storage can be or not to be used in agreement with the user's need, this way does not need to assist the whole demand of the consumer, because the system would just complement the energy supplied by the distribution grid. Considering although the use 
of the energy generated by the photovoltaic system, discounting the total losses in situations where there is excess of energy in relation to the consumption, this can be stored or then injected in the electric system of the dealership. In cases that the spare energy of the system is injected in the grid of urban distribution is generated a credit of energy automatically to the system's owner. In another way it can be stored for night use.

The energy generated by the photovoltaic systems is in general more faced than the conventional energy supplied by the electric company, as study accomplished by Reis (2002). In spite of the production processes of photovoltaic plates, they are receiving countless improvements; according to Wenham and Green (1996) the reduction in the final cost of the photovoltaic modules is still very expensive. The medium cost of the energy generated by a photovoltaic system rotates is around U\$ 0.25 / kWh (Reis, 2002), depending on the techniques joined to the system, this cost can be more expensive. However the fall projections in the prices of the photovoltaic panels show that these systems can become a quite attractive investment in a short time. On the other hand, auxiliary generation systems with primary sources of energy made it available with no cost, they possess an investment return in a very attractive time, considering the current costs of the electric power.

\section{Proposed System}

The present luminous energy in the solar rays is captured through a group of solar panels that take advantage of the photovoltaic effect of the semiconductors to convert the luminous energy to electric power, according to GTES (1999). The photovoltaic panels existent commercially allow several types of arrangements to be made according to the need and the wanted application. The topology of the photovoltaic generation system, object of study of this article, is showed on the Fig. 1.

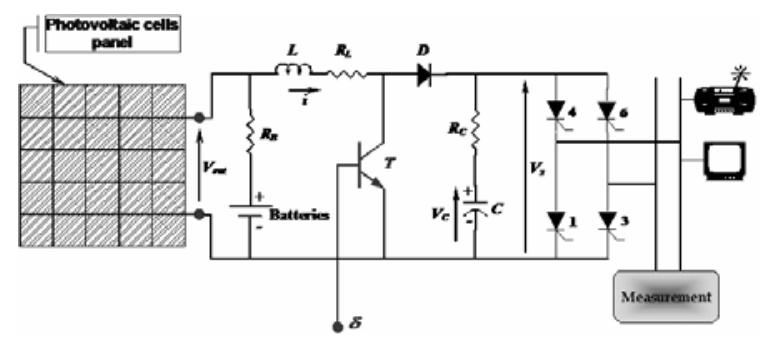

Figure 1. Topology of the residential photovoltaic generation system.

The photovoltaic modules are used in the healthy project of the type policrystalline, with the characteristics presented on the Tab. 1.
Table 1. Characteristics of the photovoltaic modules of the project, obtained from technical informatives for $\mathrm{E}=1,000 \mathrm{~W} / \mathrm{m}^{2}$.

\begin{tabular}{|c|c|c|}
\hline Characteristics & Value & $\begin{array}{c}\text { Data for array } \\
\text { used }\end{array}$ \\
\hline Nominal power & $50 \mathrm{~W}_{\mathrm{p}}$ & $4 \times 50 \mathrm{~W}_{\mathrm{p}}$ \\
\hline Nominal current & $2.9 \mathrm{~A}$ & $5.8 \mathrm{~A}$ \\
\hline $\begin{array}{c}\text { Short-circuit } \\
\text { current }\end{array}$ & $3.1 \mathrm{~A}$ & $6.2 \mathrm{~A}$ \\
\hline Nominal voltage & $17.2 \mathrm{~V}$ & $34.4 \mathrm{~V}$ \\
\hline $\begin{array}{c}\text { Open circuit } \\
\text { voltage }\end{array}$ & $21.6 \mathrm{~V}$ & $43.2 \mathrm{~V}$ \\
\hline Cells numbers & 36 & - \\
\hline $\begin{array}{c}\text { Dimensions } \\
1,042 \times 462 \mathrm{x} \\
39 \mathrm{~mm}\end{array}$ & $\begin{array}{c}1,042 \times 1848 \\
\mathrm{x} \mathrm{39} \mathrm{mm}\end{array}$ \\
\hline Weight & $9.2 \mathrm{~kg}$ & $36.8 \mathrm{~kg}$ \\
\hline
\end{tabular}

The system uses a group of four photovoltaic panels of 50 Watt of pick $\left(\mathrm{W}_{\mathrm{p}}\right)$ associated in series of two to two and connected to the two groups series, in parallel in such a way to obtain the nominal output voltage of $34.4 \mathrm{~V}$, this value is designated by Vent on the topology viewed on the Fig. 1. Those technical data for nominal condition are equal to a solar radiation of $1,000 \mathrm{~W} / \mathrm{m}^{2}$, established value as pattern for the manufacturers.

The joining of the photovoltaic modules with the electric grid, in alternating current voltage $\left(\mathrm{V}_{\mathrm{AC}}\right)$, will be through a totally controlled monophase converter bridge. Pelly (1971) proposes that the monophase bridge rectifier with four thyristors can still operate as an inverter, transferring the power beside direct current voltage $\left(\mathrm{V}_{\mathrm{DC}}\right)$ to the side of alternating current voltage $\left(\mathrm{V}_{\mathrm{AC}}\right)$. The medium voltage on the DC side of the bridge can be obtained by Eq. (1).

$$
\mathrm{V}_{(\mathrm{CC})}=\frac{2 \sqrt{2}}{\pi} \cdot 220 \cdot \cos \alpha
$$

This inverter type possesses an important characteristic for the choice of this topology, in other words, the system operation that always needs that voltage on the AC side exists, so the power flow occurs. This characteristic will be used as a natural protection for the generation system, because in the lack of energy in the AC grid, it can be inhibited by the thyristors that impedes the voltage of feeding back as soon as the distribution grid could cause irreparable damages to the circuits of the system.

Controlled converters possess a strip of typical operation for the thyristor shot angle $(\alpha)$ between $120^{\circ}$ and $150^{\circ}$. Equation (1) shows that the strip of the necessary voltage on the DC side, for the inverter to operate is between $-99 \mathrm{~V}$ and $-171 \mathrm{~V}$. In this case, considering the nominal voltage of the photovoltaic modules as $34.4 \mathrm{~V}$ and the variation in the luminous radiation, it affects the value of the generated voltage; it should settle a converter elevating type between the 
photovoltaic panel and the converter bridge, as it is viewed on Fig. 1. Through the work cycle of the elevating converter $(\delta)$ the voltage will be controlled by the input of the bridge.

The variations in the output voltage of a photovoltaic group in function of the variation of the solar radiation intensity (E) during the day are showed on the curves of the Fig. 2(A), supplied by ASE (Germany, 2000). It is still due to the accounting in the project that the influence of the temperature may affect the generated voltage, reducing its value as the photovoltaic modules temperature increases. This situation is showed on the graph of the Fig. 2(B), denominated by the influence of the temperature. It suits to notice the displacement of the voltage point in open circuit $\left(\mathrm{V}_{\mathrm{OC}}\right)$ when the temperature increases on the modules.

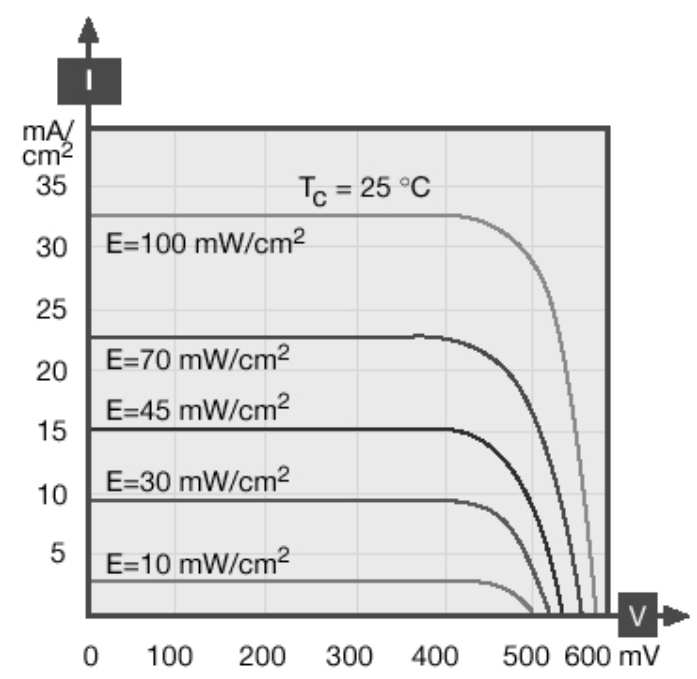

(a)

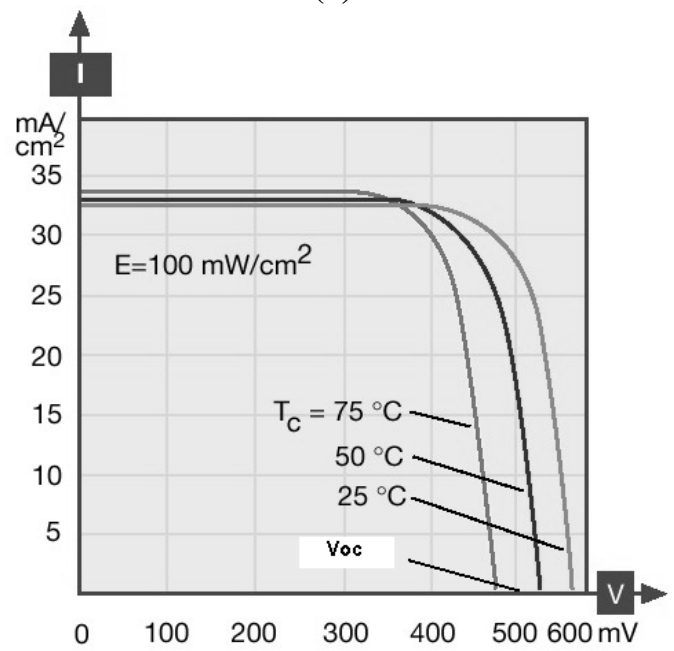

(b)

Figure 2. Behaviour of the voltage and current in a $100 \mathrm{~mm} \times 100 \mathrm{~mm}$ cell used in photovoltaic modules: (A) with the variation of the solar radiation; (B) with the variation of the temperature.
It still can increase a bank of batteries to the proposed system to be connected to the output of the photovoltaic group in such a way that when the energy generated by the panel is not injected in the electric system, the spare energy will carry the bank of batteries. The energy of the bank can be used during the night when the panel is not generating.

\section{The model of the photovoltaic group used}

The model of the photovoltaic system used in this work was developed by Bose, Szczesny, and Steigerwald (1984) and modified by Reis (2002), such as Eq. (2).

$$
I=I_{L G}-I_{o}\left\{e^{\left[\frac{q}{A K T}\left(V-R_{S} I_{A}\right)\right]}-1\right\}
$$

Where:

$$
\begin{gathered}
\mathrm{I}_{\mathrm{o}}=\mathrm{I}_{\mathrm{or}}\left[\frac{\mathrm{T}}{\mathrm{T}_{\mathrm{r}}}\right]^{3} \mathrm{e}^{\left[\frac{\mathrm{qE} \mathrm{E}_{\mathrm{GO}}}{\mathrm{BK}}\left(\frac{1}{\mathrm{~T}_{\mathrm{r}}}-\frac{1}{\mathrm{~T}}\right)\right]} \\
\mathrm{I}_{\mathrm{LG}}=\left[\mathrm{I}_{\mathrm{SCR}}+\mathrm{K}_{\mathrm{t}}\left(\mathrm{T}_{\mathrm{C}}-28\right)\right] \frac{\lambda_{\mathrm{S}}}{100}
\end{gathered}
$$

With:

$\frac{\mathrm{K}}{\mathrm{T}}=8.62 \times 10^{-5}[\mathrm{eV} / \mathrm{K}] \quad$ reason between the constant of Boltzmann and the load of the electron.

Using simulation programmes, simulated results for the group of the photovoltaic modules used may be obtained. On Figure 3 there are the characteristic curves of voltage against current and current against power.

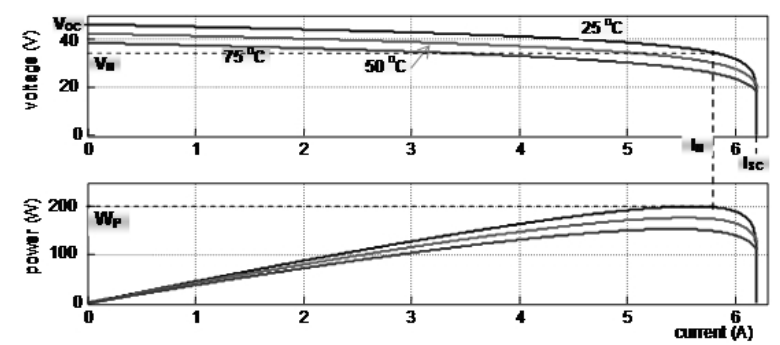

Figure 3. Result of simulations using the model of the panel: graph of current against voltage and current against power.

The graph, on the Fig. 3, shows that the power decreases with the increase of the panel temperature, an other important aspect to be observed refers to the data presented on Tab. 1 for condition of maximum solar radiation: pick power $\left(\mathrm{W}_{\mathrm{P}}\right)$, short circuit current $\left(\mathrm{I}_{\mathrm{SC}}\right)$, open circuit voltage $\left(\mathrm{V}_{\mathrm{OC}}\right)$, nominal voltage $\left(\mathrm{V}_{\mathrm{N}}\right)$ and nominal current $\left(\mathrm{I}_{\mathrm{N}}\right)$, then they are fully confirmed by the simulations. 


\section{FUZZY CONTROLLER USED}

In the fuzzy controller modelling is necessary to determine points of maximum power of the photovoltaic panel, considering the variation of the solar radiation (E), and also the effects of the temperature (T), previously discussed. The rising for obtaining those points can be obtained from technical informatives, supplied by the manufacturers of photovoltaic modules, as it is established in Reis (2002). In this case the sought points will be obtained starting from the developed model, as Fig. 4 shows.
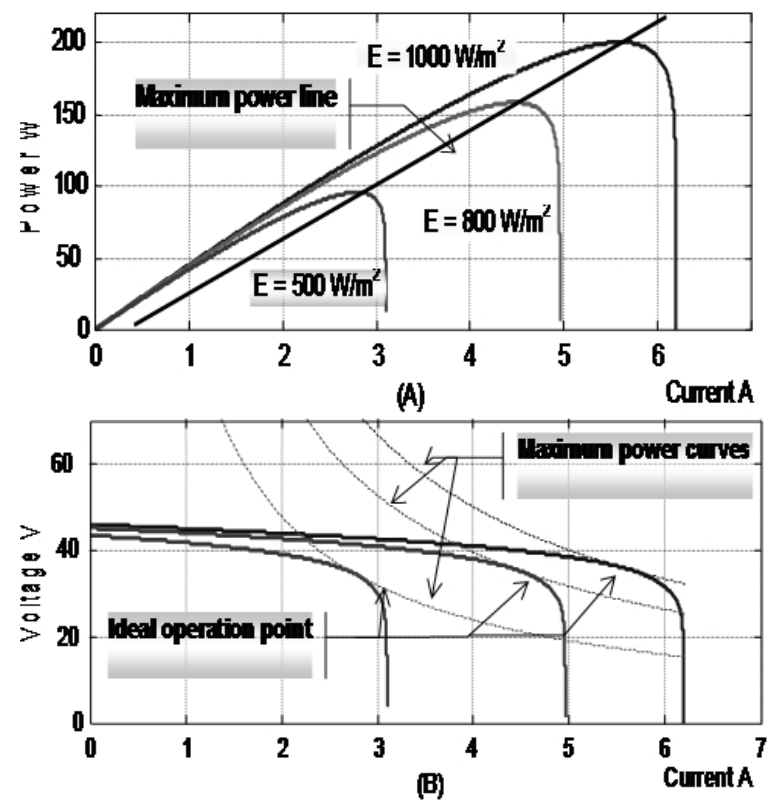

Figure 4. Determination of the maximum power points for photovoltaic system operation.

Figure 4 shows on its graph the typical curves of output current in function of the output voltage $(\mathrm{IS}=\mathrm{f}(\mathrm{VS})$ ) considering three situations for solar radiation. The traced curves are the respective curves for constant power of the panel. Name them curves if they intercept in the point of maximum power, that is the ideal operation point for photovoltaic panel; in this point, the maximum transfer of power from the photovoltaic panel to the load happens.

They can also obtain points of maxim power through the plan of the photovoltaic panel power curves, using the developed model too, as it can be observed on the power graph against the current on Fig. 4(A). Each one of the power curves is associated to the respective solar radiation. The point of curves maximum power corresponds to the product of the voltage for the current on the point that the curves of the Fig. 4(B) are intercepted. For all the three situations the points are obtained from where the respective potencies are in their maximum, these points are on the straight line of maximum power drawn on the graph and they can be represented through the line matrices defined by Eqs. (5) and (6): of maximum power $\left(\mathrm{P}_{\max }\right)$ and solar radiation $(\mathrm{E})$.

$$
\begin{aligned}
\mathrm{P}_{\max } & =\left|\begin{array}{lll}
199.9 & 158 & 95.6
\end{array}\right| \mathrm{W} \\
\mathrm{E} & =\left|\begin{array}{lll}
100 & 80 & 50
\end{array}\right| \frac{\mathrm{W}}{\mathrm{cm}^{2}}
\end{aligned}
$$

For the reduction correction of maximum power point, due to the temperature effect, it is also used a first order polynomial in the normalized form (pu). Therefore the points that define the sought straight line are suitable in the temperature $(\mathrm{T})$ and in the correction factor of the maximum power $\left(\mathrm{f}_{\mathrm{CP} \max }\right)$ matrices represented by Eqs. (7) and (8).

$$
\begin{aligned}
\mathrm{T} & =\left|\begin{array}{lll}
25 & 50 & 75
\end{array}\right|^{\circ} \mathrm{C} \\
\mathrm{f}_{\mathrm{CP} \max } & =\left|\begin{array}{lll}
1 & 0.883 & 0.766
\end{array}\right|
\end{aligned}
$$

The sought polynomials are defined by using the certain matrices (Eqs. (5) to (8)). They are written in the blocks diagram viewed on Fig. 5, which shows the logic and the control dynamics to be used. The variables of the controller's input are the solar radiation and the temperature, the output variable is the work cycle $(\delta)$ of the elevating converter.

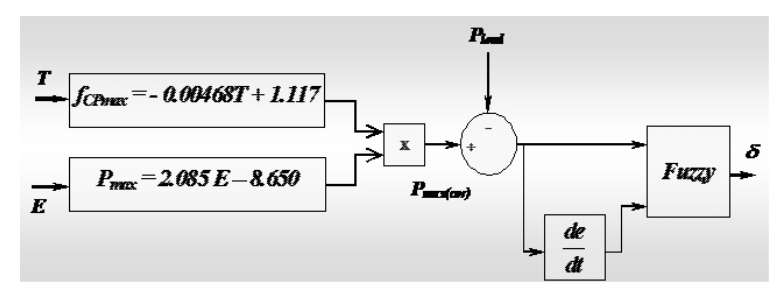

Figure 5. Blocks diagram of the photovoltaic system dynamics.

\section{MODELLING OF FUZZY CONTROLLER FOR THE PHOTOVOLTAIC PANEL}

Since it is defined that the maximum power of the photovoltaic system is a function of solar radiation and temperature, the follower circuit of maximum power will always determine the ideal operation point for this system. The mathematical manipulation of error obtained for the comparison among maximum power of the photovoltaic system, and the power transferred to the load and the respective derived will define the ideal operation point through the fuzzy logic.

Using a particular language for fuzzy systems, it settles down the fuzzy group for each input and output variables. Seven fuzzy groups were chosen for input and output variables and were labelled accordingly suitable to proceed. Follow:

\footnotetext{
- NA (negative high);

- $\quad$ NM (negative medium);

- $\quad$ NB (negative low);

- $\quad$ ZZ (zero and zero);
} 
- $\quad$ PB (positive low);

- $\quad$ PM (positive medium);

- $\quad$ PA (positive high).

The graphic representation of the suitable pertinence functions on Fig. 6 refers to the power error (epot) and is derived from the power error (depot). The duty cycle $(\delta)$ was also fuzzyfied and its pertinence functions are also on the illustration.

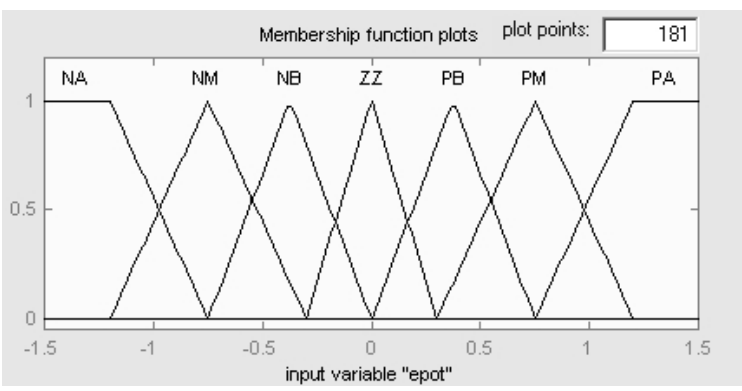

(a)

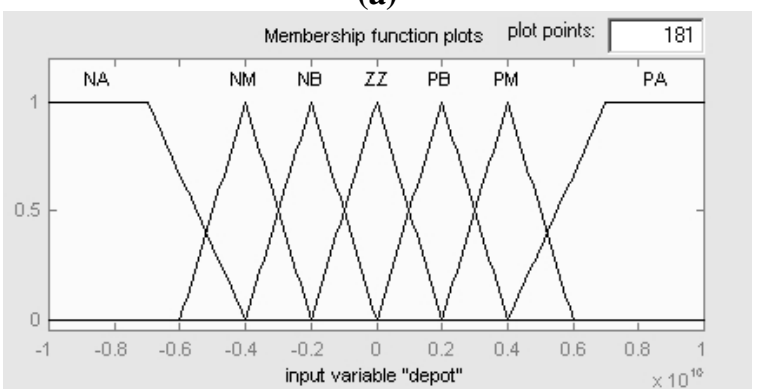

(b)

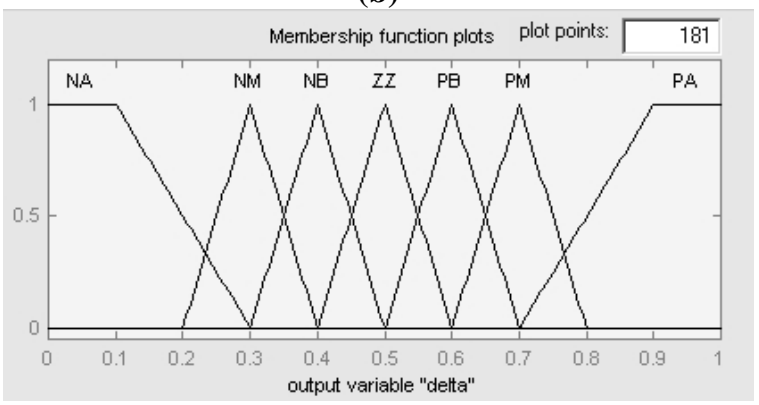

(c)

Figure 6. Representation of the input and output variables for fuzzy pertinence functions.

After pertinence functions definition the next step is to determine the fuzzy system rules, the knowledge base or the system intelligence deposit.

The rules map or matrix proposed by MacVicarWhelam (1976) should be filled out during the system identification, as suitable on Tab. 2, always aided by a specialist, in other words, a human operator to control the system. The rules used in this work are proposed by Hillowala and Sharaf (1992).
Table 2. Fuzzy rules map.

\begin{tabular}{|c|c|c|c|c|c|c|c|c|}
\hline & \multicolumn{7}{|c|}{ Error derived depot } \\
\hline & & NA & NM & NB & $\mathbf{Z Z}$ & PB & PM & PA \\
\hline & NA & $\begin{array}{l}\text { NA } \\
1\end{array}$ & $\begin{array}{l}\text { NA } \\
2\end{array}$ & $\begin{array}{l}\text { NA } \\
3\end{array}$ & $\begin{array}{l}\text { NA } \\
4\end{array}$ & $\begin{array}{l}\text { NM } \\
5 \\
\end{array}$ & $\begin{array}{l}\text { NB } \\
6 \\
\end{array}$ & $\begin{array}{l}\mathrm{ZZ} \\
7\end{array}$ \\
\hline & NM & $\begin{array}{l}\text { NA } \\
8 \\
\end{array}$ & $\begin{array}{l}\text { NA } \\
9\end{array}$ & $\begin{array}{l}\text { NM } \\
10\end{array}$ & $\begin{array}{l}\text { NM } \\
11\end{array}$ & $\begin{array}{l}\text { NB } \\
12\end{array}$ & $\begin{array}{l}\mathrm{ZZ} \\
13\end{array}$ & $\begin{array}{l}\text { PB } \\
14\end{array}$ \\
\hline & NB & $\begin{array}{l}\text { NA } \\
15\end{array}$ & $\begin{array}{l}\text { NM } \\
16\end{array}$ & $\begin{array}{l}\text { NB } \\
17\end{array}$ & $\begin{array}{l}\text { NB } \\
18\end{array}$ & $\begin{array}{l}\text { ZZ } \\
19\end{array}$ & $\begin{array}{l}\text { PB } \\
20\end{array}$ & $\begin{array}{l}\text { PM } \\
21\end{array}$ \\
\hline & ZZ & $\begin{array}{l}\text { NM } \\
22\end{array}$ & $\begin{array}{l}\text { NM } \\
23\end{array}$ & $\begin{array}{l}\text { NB } \\
24\end{array}$ & $\begin{array}{l}Z Z \\
25\end{array}$ & $\begin{array}{l}\text { PB } \\
26\end{array}$ & $\begin{array}{l}\mathrm{PM} \\
27\end{array}$ & $\begin{array}{l}\text { PM } \\
28\end{array}$ \\
\hline & PB & $\begin{array}{l}\text { NM } \\
29\end{array}$ & $\begin{array}{l}\text { NB } \\
30\end{array}$ & $\begin{array}{l}\text { ZZ } \\
31\end{array}$ & $\begin{array}{l}\text { PB } \\
32\end{array}$ & $\begin{array}{l}\text { PB } \\
33\end{array}$ & $\begin{array}{l}\mathrm{PM} \\
34\end{array}$ & $\begin{array}{l}\text { PA } \\
35\end{array}$ \\
\hline ๘े & PM & $\begin{array}{l}\text { NB } \\
36 \\
\end{array}$ & $\begin{array}{l}\mathrm{ZZ} \\
37 \\
\end{array}$ & $\begin{array}{l}\text { PB } \\
38 \\
\end{array}$ & $\begin{array}{l}\text { PM } \\
39\end{array}$ & $\begin{array}{l}\mathrm{PM} \\
40\end{array}$ & $\begin{array}{l}\text { PA } \\
41\end{array}$ & $\begin{array}{l}\text { PA } \\
42\end{array}$ \\
\hline 莣 & PA & $\begin{array}{l}\mathrm{ZZ} \\
43\end{array}$ & $\begin{array}{l}\mathrm{PB} \\
44\end{array}$ & $\begin{array}{l}\mathrm{PM} \\
45\end{array}$ & $\begin{array}{l}\text { PA } \\
46\end{array}$ & $\begin{array}{l}\text { PA } \\
47\end{array}$ & $\begin{array}{l}\text { PA } \\
48\end{array}$ & $\begin{array}{l}\text { PA } \\
49\end{array}$ \\
\hline
\end{tabular}

The operations among the proposed controller's fuzzy groups can be exemplified using the rule 16 suitable in the Tab. 2.

Rule 16: If epot is NB and depot is NM, the controller's output will be NM. This procedure will be repeated for the controller's forty nine rules.

\section{SIMULATIONS RESULTS}

Simulation results made for any situation of solar radiation variation were obtained on Fig. 7. Initially it was considered a low value of solar radiation $\left(\mathrm{E}=300 \mathrm{~W} / \mathrm{m}^{2}\right)$ and through three steps it reaches the theoretical maximum radiation of $1,000 \mathrm{~W} / \mathrm{m}^{2}$; the system stays operating in this landing for some minutes. After that the luminous radiation is reduced slowly, simulating the evening. Potencies values were obtained according to each solar radiation value, the voltage in the thyristor bridge input and the voltage in the photovoltaic modules output.
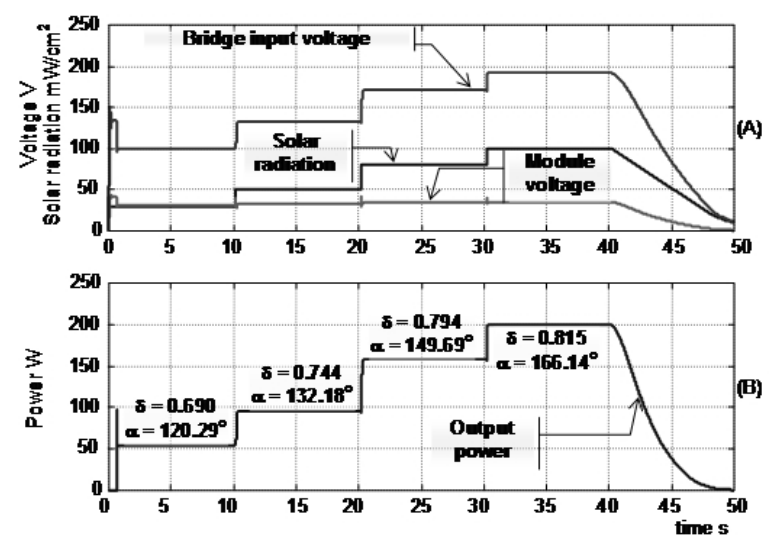

Figure 7. Simulation results for the photovoltaic module. 
On the graph of the Fig. 7(A) for the solar radiation of $30 \mathrm{~mW} / \mathrm{cm}^{2}$ (corresponding to 300 $\mathrm{W} / \mathrm{m}^{2}$ ) the voltage of approximately $100 \mathrm{~V}$ is showed in the elevating converter output, what makes the panel to inject a power of $53.9 \mathrm{~W}$ in the system, under a duty cycle $(\delta)$ of 0.690 and joining shot angle of inverter bridge $(\alpha)$ of $-120.29^{\circ}$. These are the expected values from the system proposed. For nominal radiation of $80 \mathrm{~mW} / \mathrm{cm}^{2}\left(\mathrm{E}=800 \mathrm{~W} / \mathrm{m}^{2}\right)$ the voltage value is $170 \mathrm{~V}$ in the converter output, that makes a $158 \mathrm{~W}$ power to be injected in the system, with duty cycle of 0.794 and shot angle with $149.69^{\circ}$. The maximum condition is $200 \mathrm{~W}$ and solar radiation of $100 \mathrm{~mW} / \mathrm{cm}^{2}$, exceptionally about a special point, because in practice and in the coordinates of Sao Paulo State, radiation is around $80 \mathrm{~mW} / \mathrm{cm}^{2}$.

\section{CONCLUSIONS}

Considering the used photovoltaic panel (200 $\mathrm{W}_{\mathrm{P}}$ ), operating about 5 hours a day under solar radiation of $800 \mathrm{~mW} / \mathrm{cm}^{2}$ will generate a medium energy of $30 \mathrm{kWh} / \mathrm{month}$. Comparing the energy generated with the monthly consumption of a middle class residence that consumes around $250 \mathrm{kWh}$ per month; the result is an economy from $12 \%$ a month. The economy of energy can be more significant if the power of the photovoltaic system is increased, the cost of the energy generated by the photovoltaic panels is US\$ $0.28 / \mathrm{kWh}$ against US\$ $0.23 / \mathrm{kWh}$ (according to Bandeirante Energia site) practiced by the companies of energy (considering the incident taxes).

The simulation results prove that the system is viable technically, considering although systems that use thrystors converter bridges as a technology thoroughly dominated.

Now the fuzzy logic is substituting the systems of conventional control in an extremely effective way, because they can be implemented in dedicated cards. They also present the advantage of being immune to the temperature variations and they do not need constant adjustments.

\section{ACKNOWLEDGEMENTS}

We offer our acknowledgement to FAPESP (Fundação de Amparo à Pesquisa do Estado de São Paulo) and CNPq (Conselho Nacional de Desenvolvimento Científico e Tecnológico) and their scientific scholarship system which helped in financing our work and to Grupo Semco for their equipment offerings.

\section{REFERENCES}

ANEEL, May 5th, 2005, Available in http://www.anel.gov.br.

Bose, B. K., Szczesny, P. M., and Steigerwald, R.L., 1984, Microcomputer Control of a Residential
Photovoltaic Power Conditioning System, Annual Meeting of IEEE / IAS, IAS-21, pp. 852-859.

Federal Republic of Germany, 2000, ASE GmbH - ASE 50 - ATF/17, Private Communication.

GTES, 1999, Engineering Manual for Photovoltaics Systems, CEPEL-CRESESB, Rio de Janeiro, Brazil. (In Portuguese)

Hiloowala, R. M., and Sharaf, A. M., 1992, A

Rule-based Fuzzy Logic Controller for a PWM Inverter in Photo-voltaic Energy Conversion Scheme, IEEE - Industry Application, Vol. 1, pp. 762-769.

MacVicar-Whelam, P. J., 1976, Fuzzy Sets for Man Machine Interactions, International Journal Man-Machine Studies, Vol. 8, pp. 687-697.

Pelly, B. R., 1971, Thyristor Phase-controlled Converters and Cycle-converters, John Wiley \& Sons, New York.

Reis, L. O. M., 2002, Fuzzy Logic Applied to Power Generation Hybrid System Control: Aeolian, Photovoltaic and Biogas, Doctoral Thesis, Sao Paulo State University, Guaratingueta, SP. (In Portuguese)

Wenham, S. R., and Green, M. A., 1996, Silicon Solar Cells, Progress in Photovoltaics: Research and Applications, Vol. 4. 